\title{
Short communication Evaluation of biological agents targeted at early-stage disease
} Marta Guix ${ }^{1}$, Ingrid A Mayer ${ }^{1,2}$, Ingrid M Meszoely ${ }^{2,3}$ and Carlos L Arteaga ${ }^{1,2,4}$

\author{
1Department of Medicine, Vanderbilt University School of Medicine, Nashville, TN 37232, USA \\ 2Breast Cancer Research Program, Vanderbilt-Ingram Comprehensive Cancer Center, Vanderbilt University School of Medicine, Nashville, TN 37232 , USA \\ ${ }^{3}$ Department of Surgery, Vanderbilt University School of Medicine, Nashville, TN 37232, USA \\ ${ }^{4}$ Department of Cancer Biology, Vanderbilt University School of Medicine, Nashville, TN 37232, USA
}

Corresponding author: Carlos Arteaga, carlos.arteaga@vanderbilt.edu

Published: 18 December 2008

This article is online at http://breast-cancer-research.com/content/10/S4/S25 (c) 2008 BioMed Central Ltd

In breast cancer there are many novel molecule-targeted therapies in preclinical and clinical development. For the majority, if not all, of these therapies there is no clear biomarker profile in tumours to inform the inclusion or exclusion of patients into phase II efficacy trials of these drugs or combinations that include them. Some data suggest that short-term, tissue-based pharmacodynamic trials in newly diagnosed early-stage operable cancers provide information that can be later used in patient selection. For example, administration of anti-oestrogens for a period of 1 to 3 weeks has been shown to induce a significant antiproliferative effect in oestrogen receptor (ER)-positive breast cancers [1-3]. These studies have evaluated proliferation in the tumour by measuring the percentage of cells that stain with an antibody against the nuclear antigen Ki67 [4]. Interestingly, in all of these trials there was no effect in the ER-negative cancers.

In other neoadjuvant trials, short-term end-points have correlated with clinical outcome. For example, treatment-induced tumour cell apoptosis, as measured by cleaved caspase-3 immunohistochemistry 1 week after administration of the antihuman epidermal growth factor receptor (HER)-2 monoclonal trastuzumab, correlates with clinical response of HER-2 overexpressing breast cancers [5]. The neoadjuvant Immediate Preoperative Anastrozole Tamoxifen or Combined with Tamoxifen (IMPACT) trial compared anastrozole versus tamoxifen versus the two drugs combined. Drug-induced inhibition of tumour cell proliferation at 2 weeks, as measured using Ki67, was better in patients treated with anastrozole than in patients included in the other two arms [6]. This finding parallels the results of the large Anastrozole, Tamoxifen, Alone or in Combination (ATAC) adjuvant trial, in which relapse-free survival was greater in patients treated with adjuvant anastrozole than in those receiving tamoxifen or the combination [7].
Breast Cancer Research 2008, 10(Suppl 4):S25 (doi:10.1186/bcr2185)

Recent pharmacodynamic studies of epidermal growth factor receptor (EGFR) inhibitors have provided some clues that might be of clinical use, as this approach can be potentially applied to other novel compounds and/or combinations. Guix and coworkers [8] administered erlotinib for 6 to 14 days to women with operable untreated breast cancer in order to identify a biomarker associated with evidence of drugmediated cellular activity in the surgical specimen. Erlotinib inhibited cell proliferation (Ki67) and phosphorylated EGFR, mitogen-activated protein kinase (MAPK), Akt and S6 only in ER-positive tumours, and not in HER-2-positive or triple negative tumours. These data are consistent with at least three reports showing that clinical activity of gefitinib appears to be limited to ER-positive breast cancers [9-11]. Interestingly, erlotinib inhibited phosphorylation of ER- $\alpha$ in Ser118. Similar results were reported by Polychronis and coworkers [11] in ER-positive/EGFR-positive newly diagnosed breast cancers treated for 6 weeks with neoadjuvant gefitinib. Because phosphorylation of this site is regulated mainly by MAPK [12], these findings provide evidence of operative crosstalk between ER and ErbB receptor signalling early in the natural history of hormone-dependent breast cancer. In addition, they imply that the use of EGFR antagonists in combination with anti-oestrogens should be explored in further clinical trials.

Indeed, preliminary communication of results from clinical trials already suggests this strategy to be effective. Cristofanilli and coworkers [13] recently reported the results of a randomized phase II study of anastrozole plus gefitinib versus anastrozole plus placebo in postmenopausal women with hormone receptor positive metastatic breast cancer. Fifty patients received anastrozole plus placebo and 43 the aromatase and EGFR inhibitors combined. Patients treated with this combination exhibited a median progression-free

EGFR = epidermal growth factor receptor; ER = oestrogen receptor; HER = human epidermal growth factor receptor; MAPK $=$ mitogen-activated protein kinase; $\mathrm{PFS}=$ progression-free survival. 
survival (PFS) of 14.5 months, as compared with 8.1 months in the anastrozole plus placebo control arm of the trial. Follow-up was too short to estimate overall survival. A similar randomized phase II trial was reported by Osborne and coworkers [14]. Patients with new ER-positive metastatic disease or who had recurred after adjuvant tamoxifen or had recurred during or after adjuvant therapy with an aromatase inhibitor were randomly assigned to tamoxifen with/without gefitinib. The PFS was 10.9 months versus 8.8 months in the combination versus the tamoxifen arm, with a PFS hazard ratio of 0.84 [14].

The results of these two studies in patients with ER-positive metastatic disease should be contrasted with those of a 16-week neoadjuvant trial of anastrozole with/without gefitinib in patients with stage I to IIIB ER-positive breast cancer [15]. In this study, objective response exhibited a nonsignificant trend against the combination versus the anastrozole arm (48\% versus $61 \%$ ). This difference was statistically significant in the progesterone receptor positive group. Lack of patient selection, prior adjuvant therapy, different stage of disease (localized versus metastatic) and study end-points (response versus PFS) may potentially account for the discrepancy in results.

The presurgical studies discussed above support the feasibility of testing novel therapies during the pre-approval process to investigate a tumour profile of potential use in subsequent clinical studies that address drug efficacy. This approach requires additional examples and experience. We speculate, though, that this trial design may expedite the drug development process by potentially informing the exclusion of nonresponsive patients who will dilute the net signal of clinical activity of a drug or a combination. In the case of erlotinib, these patients would be those with HER-2-positive and triple-negative, basal-like cancers. Interestingly, because of its relative over-expression in breast cancers with a basal-like gene expression signature [16], the EGFR has been proposed as a therapeutic target in tumours that lack ER and HER-2. However, in two recent trials in patients with triple-negative, basal-type metastatic breast cancer, the addition of the EGFR antibody cetuximab did not add to the effect of chemotherapy $[17,18]$.

In summary, we believe that the evaluation of biological agents in early-stage breast cancer, where tumour tissue is available, provides outstanding opportunities for accelerated drug development, biomarker discovery and, eventually, patient selection. It can potentially validate inhibition of the molecular target of the drug; identify subgroups of patients who may not be candidates for the drug in question (triple negative tumours for EGFR inhibitors, to follow the example above); and provide knowledge to assist in a 'go versus no-go' decision regarding progression to phase II or III drug development.

\section{Competing interests}

The authors declare that they have no competing interests.

\section{Acknowledgements}

Supported in part by NCl R01 CA62212, R01 CA80195, ACS Clinical Research Professorship Grant CRP-07-234, a grant from the Entertainment Industry Foundation, Breast Cancer Specialized Program of Research Excellence (SPORE) P50 CA98131, and Vanderbilt-Ingram Comprehensive Cancer Center Support Grant P30 CA68485.

This article has been published as part of Breast Cancer Research Volume 10 Supplement 4, 2008: Controversies in Breast Cancer 2008. The full contents of the supplement are available online at http://breast-cancer-research.com/supplements/10/S4

\section{References}

1. Dowsett M, Dixon JM, Horgan K, Salter J, Hills M, Harvey E: Antiproliferative effects of idoxifene in a placebo-controlled trial in primary human breast cancer. Clin Cancer Res 2000, 6: 2260-2267.

2. Dowsett M, Bundred NJ, Decensi A, Sainsbury RC, Lu Y, Hills MJ, Cohen FJ, Veronesi P, O'Brien ME, Scott T, Muchmore DB: Effect of raloxifene on breast cancer cell Ki67 and apoptosis: a double-blind, placebo-controlled, randomized clinical trial in postmenopausal patients. Cancer Epidemiol Biomarkers Prev 2001, 10:961-966.

3. DeFriend DJ, Howell A, Nicholson RI, Anderson E, Dowsett M, Mansel RE, Blamey RW, Bundred NJ, Robertson JF, Saunders C, Baum M, Walton P, Sutcliffe F, Wakeling AE: Investigation of a new pure antiestrogen (ICl 182780) in women with primary breast cancer. Cancer Res 1994, 54:408-414.

4. Assersohn L, Salter J, Powles TJ, A'Hern R, Makris A, Gregory RK, Chang J, Dowsett M: Studies of the potential utility of Ki67 as a predictive molecular marker of clinical response in primary breast cancer. Breast Cancer Res Treat 2003, 82:113-123.

5. Mohsin SK, Weiss HL, Gutierrez MC, Chamness GC, Schiff R, Digiovanna MP, Wang CX, Hilsenbeck SG, Osborne CK, Allred DC, Elledge R, Chang JC: Neoadjuvant trastuzumab induces apoptosis in primary breast cancers. J Clin Oncol 2005, 23: 2460-2468.

6. Dowsett M, Ebbs SR, Dixon JM, Skene A, Griffith C, Boeddinghaus I, Salter J, Detre S, Hills M, Ashley S, Francis S, Walsh G, Smith IE: Biomarker changes during neoadjuvant anastrozole, tamoxifen, or the combination: influence of hormonal status and HER-2 in breast cancer-a study from the IMPACT trialists. J Clin Oncol 2005, 23:2477-2492.

7. Howell A, Cuzick J, Baum M, Buzdar A, Dowsett M, Forbes JF, Hoctin-Boes G, Houghton J, Locker GY, Tobias JS: Results of the ATAC (Arimidex, Tamoxifen, Alone or in Combination) trial after completion of 5 years' adjuvant treatment for breast cancer. Lancet 2005, 365:60-62.

8. Guix M, Granja Nde M, Meszoely I, Adkins TB, Wieman BM, Frierson KE, Sanchez V, Sanders ME, Grau AM, Mayer IA, Pestano G, Shyr Y, Muthuswamy S, Calvo B, Krontiras H, Krop IE, Kelley MC, Arteaga CL: Short preoperative treatment with erlotinib inhibits tumor cell proliferation in hormone receptor-positive breast cancers. J Clin Oncol 2008, 26:897-906.

9. Agrawal A, Gutteridge E., Cheung KL, Hyman-Taylor P, Robertson JFR: Efficacy and tolerability of gefitinib in oestrogen receptor negative and tamoxifen resistant oestrogen receptor positive locally advanced or metastatic breast cancer. Breast Cancer Res Treat 2005, 24:S61.

10. Ciardiello F, Troiani T, Caputo F, De Laurentiis M, Tortora G, Palmieri G, De Vita F, Diadema MR, Orditura M, Colantuoni G, Gridelli C, Catalano G, De Placido S, Bianco AR: Phase II study of gefitinib in combination with docetaxel as first-line therapy in metastatic breast cancer. Br J Cancer 2006, 94:1604-1609.

11. Polychronis A, Sinnett HD, Hadjiminas D, Singhal H, Mansi JL, Shivapatham D, Shousha S, Jiang J, Peston D, Barrett N, Vigushin D, Morrison K, Beresford E, Ali S, Slade MJ, Coombes RC: Preoperative gefitinib versus gefitinib and anastrozole in postmenopausal patients with oestrogen-receptor positive and epidermal-growth-factor-receptor-positive primary breast cancer: a double-blind placebo-controlled phase II randomised trial. Lancet Oncol 2005, 6:383-391.

12. Sarwar N, Kim JS, Jiang J, Peston D, Sinnett HD, Madden $P$, Gee JM, Nicholson RI, Lykkesfeldt AE, Shousha S, Coombes RC, Ali $\mathrm{S}$ : Phosphorylation of ERalpha at serine 118 in primary breast 
cancer and in tamoxifen-resistant tumours is indicative of a complex role for ERalpha phosphorylation in breast cancer progression. Endocr Relat Cancer 2006, 13:851-861.

13. Cristofanilli M, Valero V, Mangalik A, Rabinowitz I, Arena FP, Kroener JF, Curcio E, Watkins C, Magill P: A phase II multicenter, double-blind, randomized trial to compare anastrozole plus gefitinib with anastrozole plus placebo in postmenopausal women with hormone receptor-positive (HR+) breast cancer (MBC). Proc Am Soc Clin Oncol 2008, 26:44s.

14. Osborne K, Neven P, Dirix L, Mackey J, Robert J, Underhill C, Gutierrez C, Magill P, Hargreaves: Randomized phase II study of gefitinib (IRESSA) or placebo in combination with tamoxifen in patients with hormone receptor positive metastatic breast cancer [abstract 2067]. Breast Cancer Res Treat 2007, 106(suppl 1):S107.

15. Smith IE, Walsh G, Skene A, Llombart A, Mayordomo Jl, Detre S, Salter J, Clark E, Magill P, Dowsett M: A phase II placebo-controlled trial of neoadjuvant anastrozole alone or with gefitinib in early breast cancer. J Clin Oncol 2007, 25:3816-3822.

16. Livasy CA, Perou CM, Karaca G, Cowan DW, Maia D, Jackson S, Tse CK, Nyante S, Millikan RC: Identification of a basal-like subtype of breast ductal carcinoma in situ. Hum Pathol 2007, 38:197-204.

17. Carey LA, Mayer E, Marcom PK, Rugo H, Liu M, Ma C, Rimawi M, Storniolo A, Forero A, Esteva F, Wolff A, Ingle J, Ferraro M, Sawyer L, Davidson N, Perou CM, Winer EP: TBCRC 001: EGFR inhibition with cetuximab in metastatic triple negative (basallike) breast cancer [abstract 307]. Breast Cancer Res Treat 2007, 106(suppl 1):S32.

18. O'Shaughnessy J, Weckstein DJ, Vukelja SJ, Mclntyre K, Krekow L, Holmes FA, Asmar L, Blum JL: Preliminary results of a randomized phase II study of weekly irinotecan/carboplatin with or without cetuximab in patients with metastatic breast cancer [abstract 308]. Breast Cancer Res Treat 2007, 106 (suppl 1):S32. 